\title{
Peran Kalsium dan Vitamin C dalam Absorpsi Zat Besi dan Kaitannya dengan Kadar Hemoglobin Ibu Hamil: Sebuah Tinjauan Sistematis
}

\author{
Elzha Geniz Rieny ${ }^{1 *}$, Sri Achadi Nugraheni ${ }^{1}$, Apoina Kartini ${ }^{1}$ \\ ${ }^{1}$ Bagian Gizi Kesehatan Masyarakat, Fakultas Kesehatan Masyarakat, Universitas Diponegoro, Semarang \\ *Corresponding author: elzhagenizrieny@gmail.com
}

Info Artikel : Diterima 09 Juli 2021 ; Disetujui 02 Oktober 2021 ; Publikasi 01 Desember 2021

\begin{abstract}
ABSTRAK
Latar belakang: Kadar hemoglobin rendah menyebabkan anemia dalam kehamilan. Faktor yang mempengaruhi kadar hemoglobin adalah zat besi, vitamin C sebagai enhancer besi, dan kalsium sebagai inhibitor besi. Tujuan penelitian ini adalah untuk mengetahui pengaruh asupan besi, kalsium, dan vitamin $\mathrm{C}$ terhadap kadar hemoglobin ibu hamil.

Metode: Penelitian ini menggunakan pendekatan tinjauan sistematis dengan metode PRISMA. Pencarian literatur menggunakan database elektronik yaitu SCOPUS, PubMed, dan Garuda dengan kata kunci: asupan besi, kalsium, vitamin C, kadar hemoglobin, ibu hamil. Pembatasan ditetapkan pada artikel: artikel asli dari sumber utama dengan teks penuh, diterbitkan sepuluh tahun terakhir, berbahasa Indonesia dan/atau Inggris. Variabel dalam artikel: pengaruh asupan besi, kalsium dan artikel terhadap kadar hemoglobin. Dari 663 artikel yang ditemukan, didapatkan 15 artikel yang memenuhi kriteria dan selanjutnya diidentifikasi.

Hasil: Asupan zat besi meningkatkan kadar hemoglobin ibu hamil. Selain zat besi, vitamin C juga membantu meningkatkan kadar hemoglobin ibu hamil. Hal ini dikarenakan vitamin $\mathrm{C}$ merupakan faktor pendukung penyerapan zat besi. Asupan zat besi yang dikonsumsi bersama vitamin $\mathrm{C}$ lebih efektif dalam meningkatkan kadar hemoglobin. Sedangkan, kalsium merupakan faktor penghambat penyerapan zat besi, sehingga kalsium menurunkan jumlah kadar hemoglobin pada ibu hamil.

Simpulan: Asupan zat besi, kalsium dan vitamin C memberikan pengaruh yang cukup signifikan pada kadar hemoglobin ibu hamil.
\end{abstract}

Kata kunci: zat besi; kalsium; vitamin C; hemoglobin.

\section{ABSTRACT}

Title: Effect of Iron Intake, Calcium, and Vitamin Con Pregnant Women's Hemoglobin Levels: Systematic Review

Background: Low hemoglobin levels cause anemia in pregnancy. Factors that affect hemoglobin levels are iron, vitamin $C$ as an iron enhancer, and calcium as an iron inhibitor. This study aims to determine the effect of iron intake, calcium, and vitamin $C$ on the hemoglobin levels of pregnant women.

Method: This study uses a systematic review approach with the PRISMA method. A literatur search using electronic databases namely, SCOPUS, PubMed, and Garuda with the following keywords: iron intake, calcium, vitamin $C$, hemoglobin levels, pregnant women. Search limits included: original and full text articles from primary sources, published in the last ten years, Indonesian and/or English language. Variables in the articles: effect of iron intake, calcium, and vitamin $C$ on hemoglobin levels. From 663 articles that founded, 15 articles were obtained fulfilling the criteria and then were identified.

Result: Iron intake increases hemoglobin levels in pregnant women. In addition to iron, vitamin $C$ also helps to increase the hemoglobin levels of pregnant women. This is because vitamin $C$ is a supporting factor for iron absorption. Iron intake consumed with vitamin $C$ is more effective in increasing hemoglobin levels. Meanwhile, calcium is a factor inhibiting the absorption of iron, so calcium lowers hemoglobin levels in pregnant women. Conclusion: Iron intake, calcium, and vitamin C has a significant influence on the hemoglobin levels of pregnant women. 
Keywords: iron; calcium; vitamin C; hemoglobin

\section{PENDAHULUAN}

Hemoglobin adalah senyawa pembawa oksigen pada darah yang dapat digunakan sebagai parameter dalam mendiagnosa anemia gizi. ${ }^{(1,2)}$ Kadar hemoglobin yang rendah dapat mengakibatkan terjadinya anemia. ${ }^{(3)}$ Prevalensi anemia ibu hamil di Indonesia, berdasarkan hasil Riset Kesehatan Dasar (Riskesdas Tahun 2018), prevalensi anemia pada ibu hamil adalah sebesar $48,9 \%$. ${ }^{(4)}$

Kekurangan zat besi akan menurunkan kecepatan pembentukan dan konsentrasi hemoglobin dalam peredaran darah, yang selanjutnya mempengaruhi status gizi ibu hamil. ${ }^{(5)}$ Salah satu faktor yang mempengaruhi kadar hemoglobin adalah konsumsi dan penyerapan zat besi dalam tubuh. Penyerapan zat besi erat kaitannya dengan konsumsi zat gizi tertentu, seperti vitamin $\mathrm{C}$ sebagai zat pendukung penyerapan dan kalsium sebagai penghambat penyerapan. ${ }^{(6)}$

Vitamin C mempunyai peran dalam pembentukan hemoglobin dalam darah, dimana vitamin $\mathrm{C}$ membantu proses penyerapan zat besi dan makanan sehingga dapat diproses menjadi sel darah merah. ${ }^{(7)}$ Selama absorpsi besi, bila total kalsium yang dikonsumsi antara 40-300 mg, maka akan terjadi interaksi antara kalsium dan zat besi. Jumlah kalsium ini dapat mengurangi penyerapan zat besi hingga $40 \% .^{(6,8)}$

Berbagai penelitian terkait hubungan asupan zat besi, kalsium dan vitamin $\mathrm{C}$ dengan kadar hemoglobin ibu hamil sudah banyak dilakukan di Indonesia dan berbagai negara lainnya. Dari hasil beberapa penelitian yang telah dilakukan, maka asupan zat besi, kalsium dan vitamin $\mathrm{C}$ dapat dianggap sebagai faktor yang mempengaruhi kadar hemoglobin ibu hamil. Namun, sebagian hasil menunjukkan hasil yang tidak sama dimana kalsium tidak memberikan pengaruh terhadap kadar hemoglobin. Masih banyaknya hasil penelitian yang tidak sama atau simpang siur terkait peran kalsium dan vitamin $\mathrm{C}$ dalam absorbsi zat besi serta kaitannya dengan kadar hemoglobin ibu hamil menjadi alasan peneliti untuk mengadakan penelitian secara tinjauan sistematis. Selain itu berdasarkan pengetahuan peneliti, sejauh ini belum ada penelitian yang mengulas secara sistematis terkait peran kalsium dan vitamin $\mathrm{C}$ dalam absorbsi zat besi serta kaitannya dengan kadar hemoglobin ibu hamil. Oleh karena itu, peneliti ingin mendiskusikan masalah terkait peran kalsium dan vitamin $\mathrm{C}$ dalam absorbsi besi serta kaitannya dengan kadar hemoglobin ibu hamil dengan menggunakan metode systematic review.

\section{MATERI DAN METODE}

Penelitian ini merupakan penelitian kualitatif dengan pendekatan tinjauan sistematis (systematic review) dan menggunakan metode PRISMA (Preferred Reporting Items for Systematic Review and Meta-Analysis). Sumber data penelitian ini berasal dari literatur berupa artikel penelitian terdahulu yang diperoleh melalui database yaitu SCOPUS, PubMed, dan Garuda. Kriteria inklusi penelitian ini adalah artikel asli dari sumber utama dengan teks penuh; diterbitkan 10 tahun terakhir; berbahasa Indonesia dan/ atau Inggris; subjek ibu hamil; serta studi dilakukan di Indonesia pada tingkat apa saja. Variabel dalam artikel: pengaruh asupan zat besi, kalsium, dan vitamin $\mathrm{C}$ terhadap kadar hemoglobin. Jurnal penerbit artikel hasil mesin pencarian nasional sekurang-kurangnya terindeks SINTA (Science and Technology Index) 4, sementara jurnal penerbit hasil mesin pencarian internasional sekurang-kurangnya terindeks Scopus dan/ atau Scimagojr Q4.

Artikel penelitian yang melewati proses penyaringan dikumpulkan dan dibuat ringkasan dalam bentuk matriks tabel. Prosedur telaah artikel yang digunakan melalui pendekatan sederhana secara sistematis dengan mensintesis data dari hasil temuan setiap artikel dan dibahas dengan menggunakan metode naratif sesuai dengan variabel yang ditentukan.

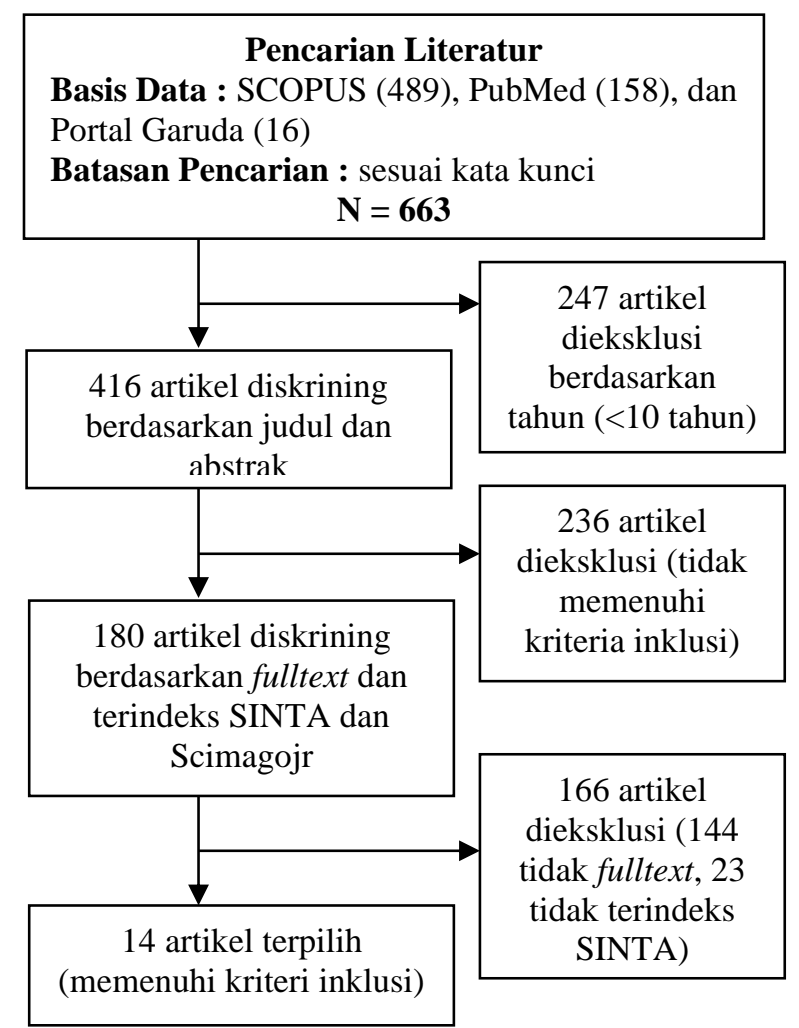

Gambar 1. Diagram alir pencarian artikel 


\section{HASIL DAN PEMBAHASAN}

Hasil penelusuran artikel pada database dengan kata kunci yang telah ditentukan, ditemukan sebanyak 15 artikel penelitian yang memenuhi kriteria inklusi sebagaimana yang dapat dilihat pada Tabel 1.

\section{Pengaruh Asupan Besi Terhadap Kadar Hemoglobin}

Dalam tinjauan sistematis ini, ditemukan sebanyak 12 artikel penelitian di Indonesia dimana variabel asupan zat besi berpengaruh terhadap kadar hemoglobin ibu hamil.(9-20) Beberapa penelitian di Indonesia melaporkan bahwa asupan zat besi meningkatkan kadar hemoglobin pada ibu hamil. Hasil ini yang sama juga didapatkan pada penelitian yang dilakukan oleh Murni (2014) yang menyatakan bahwa ada perbedaan signifikan antara kadar $\mathrm{Hb}$ ibu hamil sebelum dan sesudah pemberian Fe.(21) Keterkaitan antara zat besi dengan kadar $\mathrm{Hb}$ dapat dijelaskan bahwa zat besi merupakan komponen utama yang memegang peranan penting dalam pembentukan darah (hemopoiesis), yaitu mensintesis hemoglobin. Di samping itu, berbagai jenis enzim memerlukan Fe sebagai faktor penggiat.(15) Pada saat hamil diperlukan penambahan asupan besi baik lewat makanan maupun pemberian suplementasi tablet besi. Suplementasi tablet besi terbukti mampu mencegah penurunan kadar hemoglobin akibat hemodilusi. Pemberian tablet besi dapat meningkatkan kadar hemoglobin paling sedikit sebesar $0,3 \mathrm{gr} / \mathrm{dL} / \mathrm{minggu}$ atau selama 10 hari.(15,22) Pemberian suplementasi tablet besi selama kehamilan merupakan salah satu cara yang paling cocok bagi ibu hamil untuk meningkatkan kadar hemoglobin. Peningkatan kadar $\mathrm{Hb}$ ibu hamil tidak hanya dipengaruhi oleh suplementasi Fe saja tetapi didukung oleh konsumsi makanan yang kaya akan zat besi itu sendiri, utamanya dari zat besi heme yang terdapat dalam hewani yang absorbsiinya sampai $25 \%$, sayuran hijau sebagai sumber besi non-heme yang baik pula dan buah-buahan sebagai sumber vitamin $C$ yang membantu penyerapan zat besi dalam tubuh. Zat besi heme mempunyai bioavailabilitas yang tinggi dibandingkan zat besi non-heme. Absorbsii zat besi heme dapat mencapai $7-22 \%$ dibanding non-heme yang hanya 1-6\%, namun ratarata absorbsii zat besi hanyalah $10 \% .(13,14)$

Zat besi heme lebih mudah diserap dan penyerapannya tidak tergantung dengan zat makanan lainnya dan hanya sedikit dipengaruhi oleh status besi seseorang yang mengonsumsinya. Namun zat besi heme bisa berubah menjadi zat besi non-heme jika dimasak dengan suhu tinggi dan waktu yang lama, karena akan mengakibatkan perubahan dari hemoglobin dan struktur myoglobin yang dikandung dalam makanan tersebut.(12,23) Absorpsi dalam zat besi non-heme mempunyai kadar yang cukup rendah, walaupun zat besi hon-heme banyak mengandung mineral yang dibutuhkan tubuh. Namun dalam ada zat yang disebut asam fitat dan oksalat yang terkandung didalamnya yang dapat mengikat besi dan mengurangi penyerapannya karena keberadaan asam fitat dalam makanan merupakan penyebab utama menurunnya zat besi.(12,23) Defisit zat besi bukan merupakan penyebab tunggal rendahnya kadar hemoglobin dalam tubuh, tetapi juga dipengaruhi oleh faktor pembantu penyerapan (enhancer) seperti vitamin $C$ dan faktor penghambat penyerapan zat besi seperti kalsium, tanin, fitat, dan oksalat. $(14,24)$

Namun demikian, jika penyerapan zat besi sempurna, untuk menjadikan hemoglobin tidak hanya dibutuhkan zat besi saja tetapi juga protein khususnya asam amino glisin dan suksinil ko-A untuk menjadikan protoporpirin dan akhirnya menjadi heme setelah berinteraksi dengan zat besi dengan bantuan enzim ferrocetalase. Sedang untuk sintesa globin diperlukan asam amino, biotin, asam folat, vitamin B6, dan vitamin B12. Interaksi antara heme dan globin akan menghasilkan hemoglobin, sehingga keberadaan zat besi sangat dibutuhkan dalam sintesa heme.(25)

\section{Pengaruh Vitamin C Terhadap Kadar Hemoglobin}

Sebanyak 12 artikel penelitian ditemukan dimana variabel vitamin $\mathrm{C}$ memiliki pengaruh terhadap kadar hemoglobin ibu hamil.(9-11,13,1520,26,27) Berbagai penelitian di Indonesia menyatakan bahwa konsumsi besi yang disertai dengan vitamin $\mathrm{C}$ lebih efektif dalam meningkatkan kadar hemoglobin. Hasil serupa juga didapatkan oleh Indriani (2013) yang menyatakan bahwa ada peningkatan kadar $\mathrm{Hb}$ setelah diberikan suplementasi zat besi dan vitamin $\mathrm{C}$ dengan rerata peningkatan kadar $\mathrm{Hb}$ sebesar 2,7gr/dL.(28) Hal ini juga didukung hasil penelitian lain yang dilakukan oleh Tuti (2013) bahwa dengan pemberian tablet besi 2 kali seminggu atau sekali seminggu hasilnya akan lebih efektif dalam meningkatkan kadar $\mathrm{Hb}$ ibu hamil jika disertai dengan penambahan vitamin C.(29)

Vitamin $\mathrm{C}$ merupakan zat gizi yang termasuk dalam faktor yang dapat membantu meningkatkan atau enhancer penyerapan zat besi. Kebutuhan vitamin C selama kehamilan yang dianjurkan adalah sebanyak 85 mg.(27) Jika asupan vitamin C 100 $\mathrm{mg} /$ hari maka akan diabsorbsii secara efesien sebanyak $80-100 \%$. Pemberian vitamin C dalam bentuk tablet dapat meningkatkan penyerapan besi ibu hamil sebesar 37,5-46\%. Vitamin C mempunyai peranan yang sangat penting dalam penyerapan besi terutama dari besi nonheme yang banyak ditemukan dalam makanan nabati.(30) Vitamin C bertindak sebagai enhancer yang membentuk gugus besi askobat yang tetap larut dalam $\mathrm{pH}$ lebih tinggi dalam duodenum. Oleh karena itu ibu hamil sangat dianjurkan mengonsumsi vitamin $\mathrm{C}$ setiap kali makan. $(26,31,32)$ Vitamin $\mathrm{C}$ akan mereduksi zat besi non-heme dalam bentuk ferri menjadi ferro. 
Tabel 1. Hasil pencarian literatur artikel penelitian

\begin{tabular}{|c|c|c|c|}
\hline Metode & $\begin{array}{c}\text { Penulis dan } \\
\text { Jurnal }\end{array}$ & Sampel & Temuan \\
\hline & $\begin{array}{l}\text { Annisa dkk } \\
\text { Media Ilmu } \\
\text { Kesehatan, } \\
8(2), 2019^{(9)}\end{array}$ & $\begin{array}{l}\text { - } 15 \text { ibu hamil diberi TTD (kontrol) } \\
\text { - } 15 \text { ibu hamil diberi TTD+Vit C } \\
\text { (intervensi) } \\
\text { - Durasi : } 1 \text { bulan }\end{array}$ & $\begin{array}{l}\text { - Rata-rata kadar Hb kelompok kontrol } \\
\text { sebelum perlakuan adalah } 10,8 \mathrm{~g} / \mathrm{dL} \\
\text { meningkat menjadi } 11,1 \mathrm{~g} / \mathrm{dL} \text { setelah } \\
\text { perlakuan dengan nila beda } 0,36 \\
\text { g/dL. } \\
\text { - Rata-rata kadar Hb kelompok } \\
\text { intervensi sebelum perlakuan adalah } \\
10,7 \mathrm{~g} / \mathrm{dL} \text {, meningkat menjadi } 11,9 \\
\text { g/dL dengan nilai beda } 1,2 \mathrm{~g} / \mathrm{dL} \text {. } \\
\text { - Hasil analisis efektivitas kedua } \\
\text { kelompok tersebut didapatkan nilai } p \\
\text { value = } 0,006 \text { dengan selisih beda } \\
\text { rerata kadar Hb sebesar } 0,8 \mathrm{~g} / \mathrm{dL} \text {. } \\
\text { - Hasil analisis menunjukkan terdapat } \\
\text { perbedaan antara kedua kelompok } \\
\text { bahwa pemberian TTD disertai } \\
\text { dengan vitamin C lebih efektif dalam } \\
\text { meningkatkan kadar Hb ibu hamil } \\
\text { dibandingkan dengan pemberian } \\
\text { TTD saja. }\end{array}$ \\
\hline \multirow[t]{3}{*}{$\begin{array}{c}\text { Quasy } \\
\text { Experiment }\end{array}$} & $\begin{array}{l}\text { Desi } \\
\text { Jurnal Ilmiah } \\
\text { Bidan, 4(2), } \\
2012^{(10)}\end{array}$ & $\begin{array}{l}\text { - } 15 \text { ibu hamil diberi TTD+Vit C } \\
\text { - } 10 \text { ibu hamil diberi TTD } \\
\text { - Durasi : } 1 \text { bulan }\end{array}$ & $\begin{array}{l}\text { - Rata-rata kadar Hb kelompok } \\
\text { intervensi sebelum perlakuan adalah } \\
10,7 \mathrm{~g} / \mathrm{dL} \text {, meningkat menjadi } 12,7 \\
\text { g/dL dengan nilai beda } 2,0 \mathrm{~g} / \mathrm{dL} \text {. } \\
\text { - Rata-rata kadar Hb kelompok kontrol } \\
\text { sebelum perlakuan adalah } 9,0 \mathrm{~g} / \mathrm{dL} \text {, } \\
\text { meningkat menjadi } 10,5 \mathrm{~g} / \mathrm{dL} \text { dengan } \\
\text { nilai beda } 1,5 \mathrm{~g} / \mathrm{dL} \text {. } \\
\text { - Hasil analisis multivariat didapatkan } \\
\text { nilai } p \text { value = 0,000 dengan nilai } \\
\text { partial eta squared sebesar } 0,86 \text { yang } \\
\text { menunjukkan bahwa terdapat } \\
\text { perbedaan rerata kadar Hb antara } \\
\text { kedua kelompok. } \\
\text { - Interaksi kadar Hb antara kedua } \\
\text { kelompok didapatkan nilai } p \text { value }= \\
0,007 \text { yang menunjukkan adanya } \\
\text { perbedaan efek pada kedua kelompok } \\
\text { dengan hasil analisis multivariat } \\
\text { sebesar 0,35. }\end{array}$ \\
\hline & $\begin{array}{l}\text { Rosmiyati } \\
\text { Jurnal } \\
\text { Kebidanan, } \\
4(1), 2018^{(13)}\end{array}$ & $\begin{array}{l}\text { - } 15 \text { ibu hamil diberi tablet besi + vit } \\
\mathrm{C} \\
\text { - Durasi : } 1 \text { bulan }\end{array}$ & $\begin{array}{l}\text { - Rata-rata kadar hemoglobin ebelum } \\
\text { perlakuan adalah } 10,33 \mathrm{~g} / \mathrm{dL} \text {, } \\
\text { meingkat menjadi } 11,47 \mathrm{~g} / \mathrm{dL} \text { dengan } \\
\text { nilai beda } 1,14 \mathrm{~g} / \mathrm{dL} \text {. } \\
\text { - Hasil uji didapatkan nilai } p \text { value = } \\
0,000 \text { yang menunjukkan bahwa } \\
\text { vitamin c terbukti efektif dalam } \\
\text { meningkatkan kadar Hb apabila } \\
\text { dikonsumsi bersama tablet besi. }\end{array}$ \\
\hline & $\begin{array}{l}\text { Didik dkk } \\
\text { Jurnal } \\
\text { Vokasi } \\
\text { Kesehatan, } \\
1(5), 2015^{(17)}\end{array}$ & $\begin{array}{l}\text { - } 18 \text { ibu hamil diberi TTD+Vit C } \\
\text { - } 18 \text { ibu hamil diberi TTD } \\
\text { - Durasi : } 6 \text { bulan }\end{array}$ & $\begin{array}{l}\text { - Rerata kadar Hb kelompok intevensi } \\
\text { sebelum perlakuan adalah } 9,87 \mathrm{~g} / \mathrm{dL} \text {, } \\
\text { meningkat menjadi } 10,96 \mathrm{~g} / \mathrm{dL} \\
\text { dengan nilai beda } 1,09 \text { dan } p \text { value }= \\
0,000 \text {. }\end{array}$ \\
\hline
\end{tabular}


- Rerata kadar $\mathrm{Hb}$ kelompok kontrol sebelum perlakuan adalah $10,17 \mathrm{~g} / \mathrm{dL}$ dan meningkat menjadi $10,79 \mathrm{~g} / \mathrm{dL}$ dengan nilai beda 0,628 dan $p$ value $=0,000$.

- Hasil T test pada kedua kelompok didapatkan nilai 0,734 yang artinya terdapat perbedaan antara kedua kelompok dimana kelompok intervensi dengan pemberian TTD disertai vitamin $\mathrm{C}$ lebih efektif meningkatkan kadar $\mathrm{Hb}$.

\begin{tabular}{ll}
\hline Abdul dkk & • 30 ibu hamil diberi TTD+Vit \\
Aceh & C+Pendampingan+Penyuluhan \\
Nutrition & (FCPP) \\
Journal, 2(1), & - 30 ibu hamil diberi \\
$2017^{(19)}$ & TTD+VitC+Pendampingan (FCP) \\
& - 30 Ibu hamil diberi \\
& TTD+Pendampingan+Penyuluhan \\
& (FPP) \\
& - Durasi : 3 bulan \\
& - Dosis : TTD = 60mg Fe dan 400ug \\
& asam folat \\
& Vit C $=50 \mathrm{mg}$
\end{tabular}

- Rerata kadar Hb FCPP sebelum perlakuan adalah 10,61 g/dL, meningkat menjadi $11,50 \mathrm{~g} / \mathrm{dL}$ dengan $p$ value $=0,006$ dan selisih beda 0,89 .

- Rerata kadar $\mathrm{Hb}$ kelompok FCP adalah 10,61 g/dL dan menjadi 11,50 setelah perlakuan dengan $p$ value $=$ 0,140 dan nilai beda 0.89 .

- Rerata kadar Hb kelompok FPP adalah 10,93 g/dL dan meningkat menjadi $10,96 \mathrm{~g} / \mathrm{dL}$ setelah perlakuan dengan $p$ value $=0,888$ dan nilai beda 0,03 .

- Dari nilai $p$ yang diperoleh disimpulkan bahwa pemberian tablet Fe disertai dengan vitamin $\mathrm{C}$ lebih efektif dalam meningkatkan kadar $\mathrm{Hb}$.

\begin{tabular}{ll}
\hline Sunarsih & $\bullet 15$ ibu hamil diberi tablet Fe+jus \\
Jurnal & jeruk $250 \mathrm{cc} /$ hari \\
Kebidanan, & $\bullet 15$ ibu hamil diberi tablet Fe+Vit C \\
$5(2), 2019^{(26)}$ & $100 \mathrm{mg} /$ hari \\
& $\bullet$ Durasi : 7 hari
\end{tabular}

- Rerata kadar Hb kelompok jus jeruk sebelum perlakuan adalah $9,27 \mathrm{~g} / \mathrm{dL}$ dan menjadi 9,67 $\mathrm{g} / \mathrm{dL}$ setelah perlakuan dengan selisih 0,40 .

- Rerata kadar $\mathrm{Hb}$ kelompok vit $\mathrm{C}$ sebelum perlakuan adalah $9,33 \mathrm{~g} / \mathrm{dL}$ dan meningkat menjadi $10,07 \mathrm{~g} / \mathrm{dL}$ setelah perlakuan dengan selisih 0,74 .

- Hasil analisis bivariat didapatkan nilai $p$ value $=0,000$ dengan nilai beda 0,4 .

- Disimpulkan pemberian tablet Fe disertai vitamin C lebih efektif dalam meningkatkan kadar $\mathrm{Hb}$ dibandingkan dengan jus jeruk saja.

\begin{tabular}{ll}
\hline Risma & $\bullet 30$ ibu hamil diberi vitamin C \\
Jurnal & $\bullet$ Durasi : 6 bulan \\
Kebidanan, & \\
$6(3), 2020^{(27)}$ &
\end{tabular}

- Rerata kadar Hb sebeum perlakuan adalah 8,98 $\mathrm{g} / \mathrm{dL}$, dan setelah perlakuan adalah $12,19 \mathrm{~g} / \mathrm{dL}$ dengan selisih $3,21 \mathrm{~g} / \mathrm{dL}$.

- Nilai $p$ value $=0,0003$ yang disimpulkan bahwa pemberian vitamin $\mathrm{C}$ efektif meningkatkan kadar $\mathrm{Hb}$ ibu hamil.

\begin{tabular}{lll}
\hline Sartika dkk & $\bullet 10$ ibu hamil diberi tablet Fe & $\bullet$ Kelompok A memiliki rerata kadar \\
Jurnal & $\bullet 10$ ibu hamil diberi tablet Fe+vit C & Hb sebesar 9,93 g/dl sebelum \\
SIKLUS, & $\bullet$ Durasi : 1 bulan & perlakuan dan meningkat menjadi \\
$8(1), 2019^{(16)}$ & & $11,15 \mathrm{~g} / \mathrm{dl}$ setelah perlakuan dengan \\
\hline
\end{tabular}




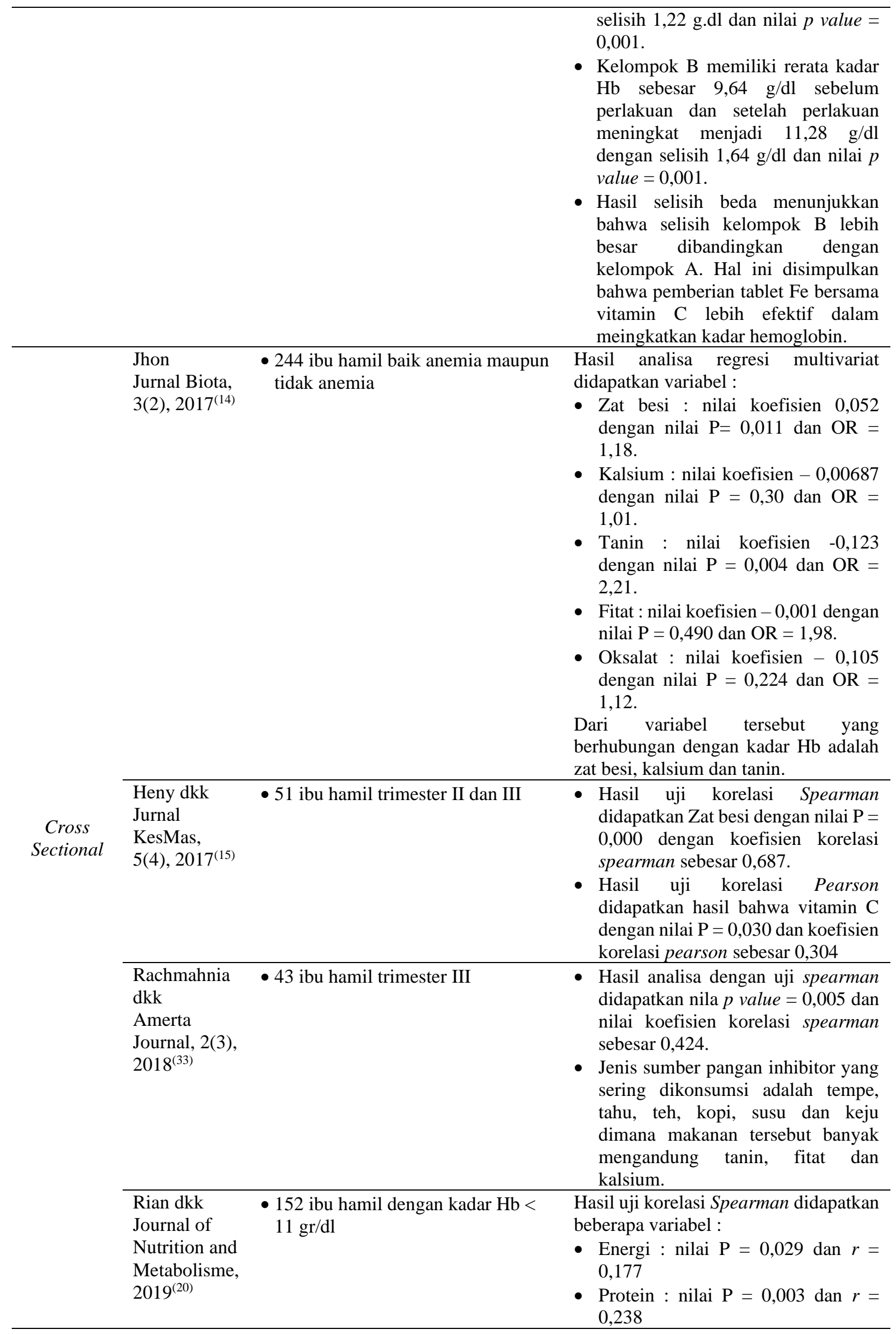




\begin{tabular}{|c|c|c|c|}
\hline & & & $\begin{array}{l}\text { - Vitamin } \mathrm{A}: \text { nilai } \mathrm{P}=0,001 \text { dan } r= \\
0,263 \\
\text { - Vitamin } \mathrm{C}: \text { nilai } \mathrm{P}=0,004 \text { dan } r= \\
0,233 \\
\text { - Kalsium : nilai } \mathrm{P}=0,078 \text { dan } r= \\
0,143 \\
\text { - Fe }: \text { nilai } \mathrm{P}=0,206 \text { dan } r=0,103 \\
\text { - Zinc : nilai } \mathrm{P}=0,015 \text { dan } r=0,197 \\
\text { Dari variabel tersebut yang } \\
\text { berhubungan dengan kadar Hb adalah } \\
\text { energy, protein, vitamin } \mathrm{A}, \text { vitamin } \mathrm{C} \\
\text { dan zink }\end{array}$ \\
\hline & $\begin{array}{l}\text { Aminah dkk } \\
\text { Pakistan } \\
\text { Journal of } \\
\text { Nutrition, } \\
14(9), \\
2015^{(11)}\end{array}$ & - 72 ibu hamil & $\begin{array}{l}\text { Hasil uji statistik didapatkan variabel } \\
\text { - Kalsium dengan nilai } \mathrm{P}=0,23 \\
\text { - } \text { Besi dengan nilai } \mathrm{P}=0,04 \\
\text { - } \text { Zink dengan nilai } \mathrm{P}=0,30 \\
\text { - Vitamin } \mathrm{C} \text { dengan nilai } \mathrm{P}=0,85 \\
\text { - Vitamin A dengan nilai } \mathrm{P}=0,04 \\
\text { - Asam Folat dengan nilai } \mathrm{P}=0 \\
\text { Dari variabel tersebut yang } \\
\text { berhubungan dengan kadar Hb adalah } \\
\text { besi, vitamin A dan asam folat. }\end{array}$ \\
\hline $\begin{array}{l}\text { True } \\
\text { Experiment }\end{array}$ & $\begin{array}{l}\text { Susilo dkk } \\
\text { Buletin } \\
\text { Penelitian } \\
\text { Sistem } \\
\text { Kesehatan, } \\
18(3), \\
2015^{(18)}\end{array}$ & $\begin{array}{l}\text { - } 21 \text { ibu hamil diberi tablet besi } \\
\text { Ferro Eksikatus 200mg + Vit C } \\
100 \mathrm{mg} \\
\text { - } 21 \mathrm{ibu} \text { hamil diberi tablet besi } \\
\text { Ferro Sulfat Eksikatus 200mg } \\
\text { - Durasi : } 60 \text { hari }\end{array}$ & $\begin{array}{l}\text { - Kelompok A memiliki rerata kadar } \\
\mathrm{Hb} 10,32 \mathrm{~g} / \mathrm{dl} \text { sebelum perlakuan } \\
\text { dan meningkat menjadi } 11,23 \mathrm{~g} / \mathrm{dl} \\
\text { dengan selisih } 1,0 \mathrm{~g} / \mathrm{dl} \text {. } \\
\text { - Kelompok B memiliki rerata kadar } \\
\mathrm{Hb} 10,27 \mathrm{~g} / \mathrm{dl} \text { sebelum perlakuan } \\
\text { dan meningkat menjadi } 10,7 \text { setelah } \\
\text { perlakuan dengan selisih } 0,43 \mathrm{~g} / \mathrm{dl} \text {. } \\
\text { - Uji analisis Independent t-test } \\
\text { didapatkan hasil signifikan pada } \\
\text { selisih kadar Hb kedua kelompok } \\
\text { perlakuan (p = 0,001). Hal ini } \\
\text { menunjukkan bahwa pemberian } \\
\text { tablet Fe dengan vitamin C lebih } \\
\text { efektif meningkatkan kadar Hb } \\
\text { dibandingkan dengan pemberian } \\
\text { tablet Fe saja. }\end{array}$ \\
\hline
\end{tabular}

Setelah diabsorbsii melalui sel mukosa akan diikat oleh apoferitin menjadi ferritin ( $\mathrm{Fe}+$ apoferitin) dan di dalam serum ikatan tersebut akan lepas dan zat besi ferro akan diangkut dalam bentuk transferin (ikatan Fe dengan protein yang mengandung 3-4 mg Fe), kemudian disimpan di dalam hati, limfa dan sumsum tulang belakang. Sebagian zat besi digunakan untuk sintesa hemoglobin (20-25 mg/hari) dan mengganti hemoglobin yang rusak (20-25 $\mathrm{mg} / \mathrm{hari})$, zat besi tersebut merupakan $60-70 \%$ dari komponen hemoglobin. $(20,30)$ Vitamin C merupakan zat yang membantu meningkatkan penyerapan dan mekanisme metabolism besi didalam tubuh. Namun, apabila jumlah vitamin $\mathrm{C}$ tidak cukup ataupun mengonsumsi vitamin $\mathrm{C}$ dengan tidak diimbangi mengonsumsi zat besi yang cukup maka fungsi vitamin $\mathrm{C}$ didalam tubuh dalam penyerapan zat besi pun tidak dapat berfungsi secara optimal, akibatnya akan berdampak pada penurunan kadar hemoglobin. $(26,27)$

Kekurangan vitamin $\mathrm{C}$ dapat disebabkan oleh kurangnya asupan makanan atau bahan makanan yang mengandung vitamin $\mathrm{C}$ dan/ atau kesalahan dalam pengolahan makanan. Kandungan vitamin yang tinggi dalam makanan akan hilang sampai $80 \%$ dalam proses pengolahan. Hal ini dikarenakan vitamin $\mathrm{C}$ mudah sekali terdegradasi, baik oleh temperatur, cahaya maupun udara sekitar. Vitamin C bersifat mudah larut dalam air sehingga membuat kandungannya mudah hilang apabila terdapat luka di permukaan atau pada waktu pemotongan bahan pangan. Vitamin C dapat ditemukan di buah citrus, tomat, sayuran berwarna hijau dan kentang. ${ }^{(20)}$

\section{Pengaruh Kalsium Terhadap Kadar Hemoglobin}

Terdapat 4 artikel penelitian yang ditemukan dari hasil pencarian literatur dimana variabel kalsium 
memberikan pengaruh terhadap kadar hemoglobin ibu hamil.(11,14,20,33) Berbagai penelitian tersebut menunjukkan bahwa konsumsi kalsium menurunkan kadar hemoglobin pada ibu hamil secara signifikan. Hasil yang sama juga ditemukan oleh Deviana (2017) bahwa terdapat hubungan antara pola konsumsi faktor inhibitor zat besi dengan status anemia pada siswi. ${ }^{(34)}$ Hasil penelitian Nisa (2019) juga menunjukkan bahwa ibu hamil yang mengalami anemia sebanyak $60 \%$ sering mengonsumsi sumber makanan faktor inhibitor. ${ }^{(35)}$

Kalsium merupakan zat gizi yang termasuk dalam faktor penghambat atau inhibitor penyerapan zat besi. ${ }^{(36)}$ Kalsium akan menigkat zat besi sebelum diserap oleh mukosa usus menjadi zat yang tidak dapat larut, sehingga akan mengurangi penyerapannya. Dengan berkurangnya penyerapan zat besi, karena faktor penghambat tersebut, maka jumlah ferritin juga akan berkurang yang berdampak pada menurunnya jumlah zat besi yang akan digunakan untuk sintesa hemoglobin dan mengganti hemoglobin yang rusak. Hal ini menyebabkan kadar hemoglobin dalam darah menjadi rendah. ${ }^{(37)}$ Kalsium fosfat akan menurunkan penyerapan zat besi nonheme sebesar $50 \%$ dan garam kalsium akan menurunkan $55 \%$ penyerapan zat besi. Penambahan $165 \mathrm{mg}$ kalsium dalam bentuk Kalsium Klorida $\left(\mathrm{CaCl}_{2}\right)$, susu, atau keju akan menurunkan penyerapan besi non-heme sebesar 50-60\% dan juga menurunkan penyerapan besi heme. Efek inhibitor untuk kalsium terlihat jika mengonsumsi dosis lebih dari $300 \mathrm{mg}$ kalsium perhari. Konsumsi kalsium sebanyak $937 \mathrm{mg}$ perhari menyebabkan zat besi yang dapat diserap sebesar $0,4 \mathrm{mg} .^{(38)}$

Berbeda dengan kalsium sitrat dan kalsium karbonat yang sebanyak $300 \mathrm{mg}$ atau $600 \mathrm{mg}$ tidak akan memberikan efek penurunan pada suplementasi besi-sulfat yang mengandung $37 \mathrm{mg}$ atau $18 \mathrm{mg}$ zat besi tanpa disertai makanan. Namun jika disertai dengan makanan seperti hamburger, ketiga senyawa tersebut akan memberikan efek penghambat zat besi. $^{(39)}$ Pemberian $100 \mathrm{mg}$ kalsium perhari dalam bentuk kalsium karbonat selama 12 minggu bersama makanan, tidak berdampak pada kadar ferritin serum. ${ }^{(40)}$ Dampak kalsium terhadap penyerapan zat besi terlihat jika garam-garam kalsium tersebut digunakan secara rutin pada persiapan makanan. Untuk itu selama kehamilan dianjurkan untuk tidak mengonsumsi kalsium < 40mg atau $<300 \mathrm{mg}$ agar sifat penghambat pada kalsium tidak memperlihatkan dampaknya. $^{(41)}$

\section{SIMPULAN}

Zat besi memberikan pengaruh dalam meningkatkan kadar hemoglobin karena zat besi merupakan komponen utama dalam pembentukan darah, yaitu untuk sintesis hemoglobin. Peningkatan kadar hemoglobin tidak hanya dipengaruhi oleh asupan zat besi saja tetapi juga dipengaruhi oleh faktor enhancer dan faktor inhibitor penyerapan zat besi.

Vitamin C memberikan pengaruh terhadap kadar hemoglobin. Vitamin C merupakan faktor enhancer dalam penyerapan besi. Dengan mengonsumsi vitamin $\mathrm{C}$ bersama dengan tablet besi meningkatkan penyerapan zat besi sehingga kadar hemoglobin dalam darah juga meningkat.

Kalsium memberikan pengaruh terhadap kadar hemoglobin. Kalsium merupakan faktor inhibitor penyerapan besi. Apabila asupan kalsium >300 $\mathrm{mg} /$ hari dan tingkat kecukupan kalsium lebih dari batas normal dapat menghambat penyerapan besi dalam tubuh sehingga kadar hemoglobin dalam darah akan menurun. Dan dapat mengakibatkan terjadinya anemia pada ibu hamil.

\section{DAFTAR PUSTAKA}

1. Hernayanti MR. Hubungan tingkat kepatuhan dosis, waktu dan cara mengkonsumsi tablet fe dengan kejadian anemia pada ibu hamil dengan umur kehamilan 28-31 minggu di puskesmas semanu. Poltekkes Yogyakarta; 2019.

2. Dara. Faktor-Faktor Yang Mempengaruhi Kepatuhan Ibu Hamil Dalam Mengonsumsi Tablet Besi dan Kaitannya Dengan Kejadian Anemia Pada Ibu Hamil di Puskesmas Muaro Kiawai Kabupaten Pasaman Barat. Stikes Perintis Padang; 2019.

3. Rissandya ES. Hubungan Tingkat Konsumsi Protein, Besi, Kalsium dan Zink dengan Kadar Hemoglobin pada Siswi SMP Negeri 21 Semarang Tahun 2011. Universitas Diponegoro; 2011.

4. Kemenkes RI. Hasil Utama Riset Kesehata Dasar (RISKESDAS) 2018. 2018; Available from:

https://kesmas.kemkes.go.id/assets/upload/dir 519d41d8cd98f00/files/Hasil-riskesdas2018_1274.pdf

5. Ifeanyi OE. A Review on Nutritional Anaemia. Int J Adv Multidiscip Res [Internet]. 2018;5(4):11-5. Available from: http://dx.doi.org/10.22192/ijamr.2018.05.04.00 3

6. Waldvogel-Abramowski S, Waeber G, Gassner C, Buser A, Frey BM, Favrat B, et al. Physiology of iron metabolism. Transfus Med Hemotherapy. 2014;41(3):213-21.

7. WHO, De-Regil LM, Juan Pablo P-R, Metin G, Jose M, Mathai M, et al. Guideline : Daily Iron and Folic Acid Supplementation in Pregnant Women. World Heal Organ [Internet]. 2012;32. Available from: www.who.int $\% 5 \mathrm{Cn}$

8. Harris SS. The effect of calcium consumption on iron absorption and iron status. Nutr Clin Care. 2002;5(5):231-5.

9. Zulqaidah AD, Rumintang BI. Efektivitas Pemberian Tablet Tambah Darah dan Vitamin C Terhadap Kadar Hemoglobin Ibu Hamil di 
Wilayah Kerja UPT BLUD Puskesmas Meninting. Media Ilmu Kesehat. 2019;8(2):116-25.

10. Rusmiati D. Pengaruh Pemberian Suplemen Zat Besi Dengan Dan Tanpa Vitamin C Terhadap Kenaikan Kadar Hemoglobin Ibu Hamil. J Ilm Bidan. 2019;4(2):30-5.

11. Toaha A, Asad S, Hadju V, Bahar B. Factor Related to Anemia in Pregnant Women of Dayak Kenyah Tribe at Kutai Kartanegara Regency, East Kalimantan Province. Pakistan J Nutr. 2015;14(9):637-41.

12. Tamrin A. Asupan Zat Besi, Asam Folat, Dan Seng Terhadap Kadar Hemoglobin Pada Ibu Hamil Di Puskesmas Paccerakkang Kecamatan Biringakanaya Kota. Media Gizi Pangan. 2019;26(2):165.

13. Rosmiyati. Pengaruh Pemberian Tablet Besi Plus Vitamin C Terhadap Kadar Hemoglobin Ibu Hamil Di Puskesmas Ambarawa Kabupaten Pringsewu Tahun 2017. J Kebidanan [Internet]. 2018;4(1):20-4. Available from: http://oreilly.com/catalog/errata.csp?isbn $=9781$ 449340377

14. Riswanda J. Hubungan Asupan Zat Besi Dan Inhibitornya Sebagai Prediktor Kadar Hemoglobin Ibu Hamil Di Kabupaten Muara Enim. Biota. 2017;3(2):83-9.

15. Yuliati H, Widajanti L, Aruben R. Hubungan Tingkat Kecukupan Energi, Protein, Besi, Vitamin C dan Suplemen Tablet Besi Dengan Kadar Hemoglobin Ibu Hamil Trimester II dan III (Di Wilayah Kerja Puskesmas Purwanegara 2 Kabupaten Banjarnegara). J Kesehat Masy. 2017;5(4):675-82.

16. Dewi SSS, Batubara NS. Pengaruh Zat Besi Dan Vitamin C Terhadap Perubahan Kadar Hemoglobin Ibu Hamil. Siklus J Res Midwifery Politek Tegal. 2019;8(1):56-9.

17. Hariyadi D, Farida S, Mariaenywati. Efektivitas Vitamin C Terhadap Kenaikan Kadar Hb Pada Ibu Hamil Di Kecamatan Pontianak Timur. J Vokasi Kesehat. 2015;1(5):146-53.

18. Wirawan S, Khairul L, Nuriyansari B, Ristrini. Pengaruh Pemberian Tablet Besi dan Tablet Besi Plus Vitamin C terhadap Kadar Hemoglobin Ibu Hamil (Effect of Vitamin C and Tablets Fe on Haemoglobin Levels Against Pregnant Women). Bul Penelit Sist Kesehat. 2015;18(3):285-92.

19. Hadi A, Marfina M, Iskandar I. Efikasi Suplementasi Tablet Besi, Vitamin C, Penyuluhan dan Pendampingan Terhadap Kadar Hemoglobin Ibu Hamil. AcTion Aceh Nutr J. 2017;2(2):91.

20. Diana R, Khomsan A, Anwar F, Christianti DF, Kusuma R, Rachmayanti RD. Dietary Quantity and Diversity among Anemic Pregnant Women in Madura Island, Indonesia. J Nutr Metab. 2019;2019.
21. Murni H. Perbedaan Kadar $\mathrm{Hb}$ dalam Pemberian Tablet Fe pada Ibu Hamil di Wilayah Kerja Puskesmas Pakan Kamis Kabupaten Agam. J Sehat Mandiri. 2014;9(1):26-32.

22. Hiola FAA, Pantoan ST, Pakaya NA. Pengaruh Suplementasi Zat Besi Dan Vitamin C Terhadap Peningkatan Kadar Hb Pada Ibu Hamil Anemia di Wilayah Kerja Puskesmas Limboto Kabupaten Gorontalo. Madu J Kesehat Umgo. 2019;8(1):1-8.

23. Pangestika $\mathrm{P}$, Kartasurya M, Suyatno S. Hubungan Tingkat Kecukupan Besi Dengan Kadar Hemoglobin Pada Remaja Hamil Usia 15-19 Tahun (Studi Di Kelurahan Rowosari Kota Semarang Tahun 2016). J Kesehat Masy. 2016;4(3):218-32.

24. Kementerian Kesehatan Republik Indonesia. Pedoman Penatalaksanaan Pemberian Tablet Tambah Darah. Jakarta: Kemenkes RI; 2015.

25. Skolmowska D, Głąbska D. Analysis of heme and non-heme iron intake and iron dietary sources in adolescent menstruating females in a national Polish sample. Nutrients. 2019;11(5):1-21.

26. Sunarsih S, Putri S, Lathifah NS. Perbedaan Pemberian Tablet Fe Dengan Jus Jeruk Dan Tablet Fe Dengan Vitamin C Terhadap Kenaikan Kadar Hemoglobin Pada Ibu Hamil Trimester Ii. J Kebidanan Malahayati. 2019;5(2):181-7.

27. Agusmayanti R, Farich A, Anggraini A. Pemberian Vitamin C Dapat Meningkatkan Kadar Hemoglobin Pada Ibu Hamil Anemia. J Kebidanan Malahayati. 2020;6(3):342-8.

28. Indriani Y, Khomsan A, Sukandar D, Riyadi H, Zuraida R, Studi P, et al. Pengaruh Pemberian Zat Besi dan Asam Folat Dibandingkan dengan Multivitamin dan Mineral pada Pekerja Wanita Usia Subur di Agroindustri Nanas. Makara Seri Kesehat. 2013;17(1):17-25.

29. Utama TA, Listiana N, Susanti D. Perbandingan Zat Besi dengan dan Tanpa Vitamin C terhadap Kadar Hemoglobin Wanita Usia Subur Comparison Effect of Iron with and without Vitamin C to Age Hemoglobin Levels among Women of Reproductive Age. J Kesehat Masy Nas. 2013;7(8):344-8.

30. Caesaria DC. Hubungan Asupan Zat Besi dan Vitamin C Dengan Kadar Hemoglobin Ibu Hamil Di Klinik Usodo Colomadu Karanganyar. Naskah Publikasi. Universitas Muhammadiyah Surakarta; 2015.

31. Almatsier S. Prinsip Dasar Ilmu Gizi. Jakarta: Gramedia Pustaka Utama; 2010.

32. Herawati AN, Palupi NS, Andarwulan N, Efriwati E. Kontribusi Asupan Zat Besi Dan Vitamin C Terhadap Status Anemia Gizi Besi Pada Balita Indonesia. Penelit Gizi dan Makanan (The J Nutr Food Res. 2019;41(2):65- 
76.

33. Pratiwi R, Widari D. Hubungan Konsumsi Sumber Pangan Enhancer Dan Inhibitor Zat Besi Dengan Kejadian Anemia Pada Ibu Hamil. Amerta Nutr. 2018;2(3):283-91.

34. Sembiring DB. Hubungan Body Image dengan Pola Konsumsi (Faktor Inhibitor dan Enhancer $\mathrm{Fe})$ dengan Status Anemia Remaja Putri di SMA Negeri 1 Lubuk Pakam. Skripsi. Poltekkes Medan; 2017.

35. Nisa J, Chikmah AM, Zulfiana E. Perilaku Konsumsi Sumber Enhancer Dan Inhibitor Fe Dengan Kejadian Anemia Pada Kehamilan. Siklus J Res Midwifery Politek Tegal. 2019;8(1):41.

36. Lönnerdal B. Calcium and Iron Absorption Mechanisms and Public Health Relevance. Int J Vitam Nutr Res [Internet]. 2013;80(45):293-9. Available from: https://doi.org/10.1024/03009831/a000036

37. Beck KL, Conlon CA, Kruger R, Coad J. Dietary determinants of and possible solutions to iron deficiency for young women living in industrialized countries: A review. Nutrients. 2014;6(9):3747-76.

38. Candia V, Ríos-Castillo I, Carrera-Gil F, Vizcarra B, Olivares M, Chaniotakis S, et al. Effect of various calcium salts on non-heme iron bioavailability in fasted women of childbearing age. J Trace Elem Med Biol [Internet]. 2018;49:8-12. Available from: https://doi.org/10.1016/j.jtemb.2018.04.029

39. Gaitán D, Flores S, Saavedra P, Miranda C, Olivares M, Arredondo M, et al. Calcium does not inhibit the absorption of 5 milligrams of nonheme or heme iron at doses less than 800 milligrams in nonpregnant women. $\mathrm{J}$ Nutr. 2011;141(9):1652-6.

40. Ríos-Castillo I, Olivares M, Brito A, Romaña DL de, Pizarro F. One-month of calcium supplementation does not affect iron bioavailability: Arandomized controlled trial. Nutrition. 2014;30(1):44-8.

41. Ross AC, Manson JAE, Abrams SA, Aloia JF, Brannon PM, Clinton SK, et al. The 2011 report on dietary reference intakes for calcium and vitamin D from the Institute of Medicine: What clinicians need to know. J Clin Endocrinol Metab. 2011;96(1):53-8. 